\title{
Tardigrada of Xinjiang Uygur Autonomous Region, China
}

\author{
Clark W. BEASLEY* and William R. MILLER ${ }^{1)}$ \\ Department of Biology, McMurry University, Abilene, Texas 79697, U.S.A. \\ ${ }^{1)}$ Department of Biology, Baker University, Baldwin City, Kansas 66006, U.S.A. \\ *e-mail corresponding author: cbeasley@mcm.edu
}

\begin{abstract}
Relatively little is known of the Tardigrada fauna of China, and there are no previous tardigrade records for Xinjiang Uygur Autonomous Region, China's largest administrative division. Moss specimens of the Missouri Botanical Garden Herbarium (St. Louis, U.S.A.) were used as a source of tardigrades from this region. Of the 270 moss specimens sampled, 78 yielded tardigrades. Species found were Bryodelphax asiaticus, Cornechiniscus holmeni, Echiniscus blumi, Echiniscus canadensis, Echiniscus granulatus, Echiniscus testudo, Echiniscus trisetosus, Macrobiotus alekseevi, Macrobiotus mauccii, Milnesium asiaticum, Milnesium longiungue, and Milnesium tardigradum. Of the species found, the Heterotardigrada are better represented, which is probably a reflection of the higher altitudes at which the samples were taken and the arid environment of the region; the species found are primarily ones considered to be xerophilic or montane. Seven species new to China are reported.
\end{abstract}

Key words: China, Xinjiang Region, Tardigrada

\section{INTRODUCTION}

The Tardigrada fauna of China had limited study prior to the year 2000 (Rahm 1936-37a, 1936-37b, 1937; Bartos 1963; Mathews 1937a, b; Pilato 1974; Beasley \& Cleveland 1996; Beasley 1999; Yang 1999). Since that time there have been more papers published on tardigrades of China than during the previous 100 years (Kaczmarek \& Beasley 2002; Yang 2002a, 2002b, 2003; Li et al. 2004; Kaczmarek et al. 2005; Li \& Liu 2005; Li \& Wang 2005a, b, 2006; Li et al. 2005a, b; Wang \& Li 2005; Beasley et al. 2006). Despite this increase in study, there are still large areas of China that have not been investigated. Xinjiang Uygur Autonomous Region (which has also been called Sinkiang Uygur Autonomous Region), the largest administrative division in China, is about one-sixth of the area of mainland China (Fullard 1968), and has had no reports of Tardigrada. This paper records tardigrade species found in Xinjiang Region, and contains new country records for China.

\section{METHODS}

Mosses at the Missouri Botanical Garden Moss Herbarium were soaked in water for 24 hours, then the moss was removed. The water was then heated to $80{ }^{\circ} \mathrm{C}$ and enough ethyl alcohol was added to result in an $80 \%$ concentration. At a later time the samples were examined and microslides of any tardigrades present were prepared using Heinz mounting medium. The slides were ringed with a sealant.

Collection data was obtained from the Missouri Botanical Garden's moss database, MOSs TROPICOS. Figure 1 illustrates the locations of the sampling sites.
Multiple samples were collected at many of the sampling sites. Collection and identification of the mosses were by a variety of bryologists associated with the Missouri Botanical Garden. Moss samples containing Tardigrada were from the following localities:

Site 1. Hejing Co., south of zero mileage point along Du-ku Highway, Tian Shan Range, 1650-1700 m a.s.1., $43.07^{\circ} \mathrm{N} 84.30^{\circ} \mathrm{E}, 30$ July 1995 , coll. Zhao Jian-cheng, Si He.

Site 2. Hejing Co., Gongnaisi Forest Preserve, Tian Shan Range, $1800-2000 \mathrm{~m}$ a.s.l., $43.15^{\circ} \mathrm{N}$ $84.48^{\circ} \mathrm{E}, 30$ July 1995 , coll. Hu Ren-liang, Zhao Jian-cheng, Si He.

Site 3. Kuche Co., Kuche Forest Preserve, Tian Shan Range, $2500-2550 \mathrm{~m}$ a.s.1., $41.45^{\circ} \mathrm{N} 83.15^{\circ} \mathrm{E}, 31$ July 1995, coll. Si He.

Site 4. Nileke Co., Wulansadik vicinity along Du-ku Highway, Tian Shan Range, 1500-1600 m a.s.l., $44.04^{\circ} \mathrm{N} 84.47^{\circ} \mathrm{E}, 29$ July 1995 , coll. Zhao Jiancheng, Si He.

Site 5. Urumqi Co., Nanshan, Huo-xia Town, Tian Shan Range, $2300-2400 \mathrm{~m}$ a.s.1., $43.12 .69^{\circ} \mathrm{N} 87.07^{\circ} \mathrm{E}$, 24 July 1995, coll. Si He.

Site 6. Urumqi Co., Shenli (Victory) Summit, Tian Shan Range, $3990-4100 \mathrm{~m}$ a.s.1., $43.07^{\circ} \mathrm{N} 84.45^{\circ} \mathrm{E}, 25$ July 1995, coll. Si He, Zhao Jian-cheng, Hu Renliang.

Site 7. Urumqi Co., Bai-yang-gou (Poplar Valley), Tian Shan Range, 2060-2250 m a.s.1., $43.25 .46^{\circ} \mathrm{N}$ 87.09.69 ${ }^{\circ}$, 23 July 1995 , coll. Liu Zhong-ling, Zhao Jian-cheng, Si He.

Site 8. Wusu Co., Maoliugou vicinity along Du-ku Highway, Tian Shan Range, 1800-1950 m a.s.l., 


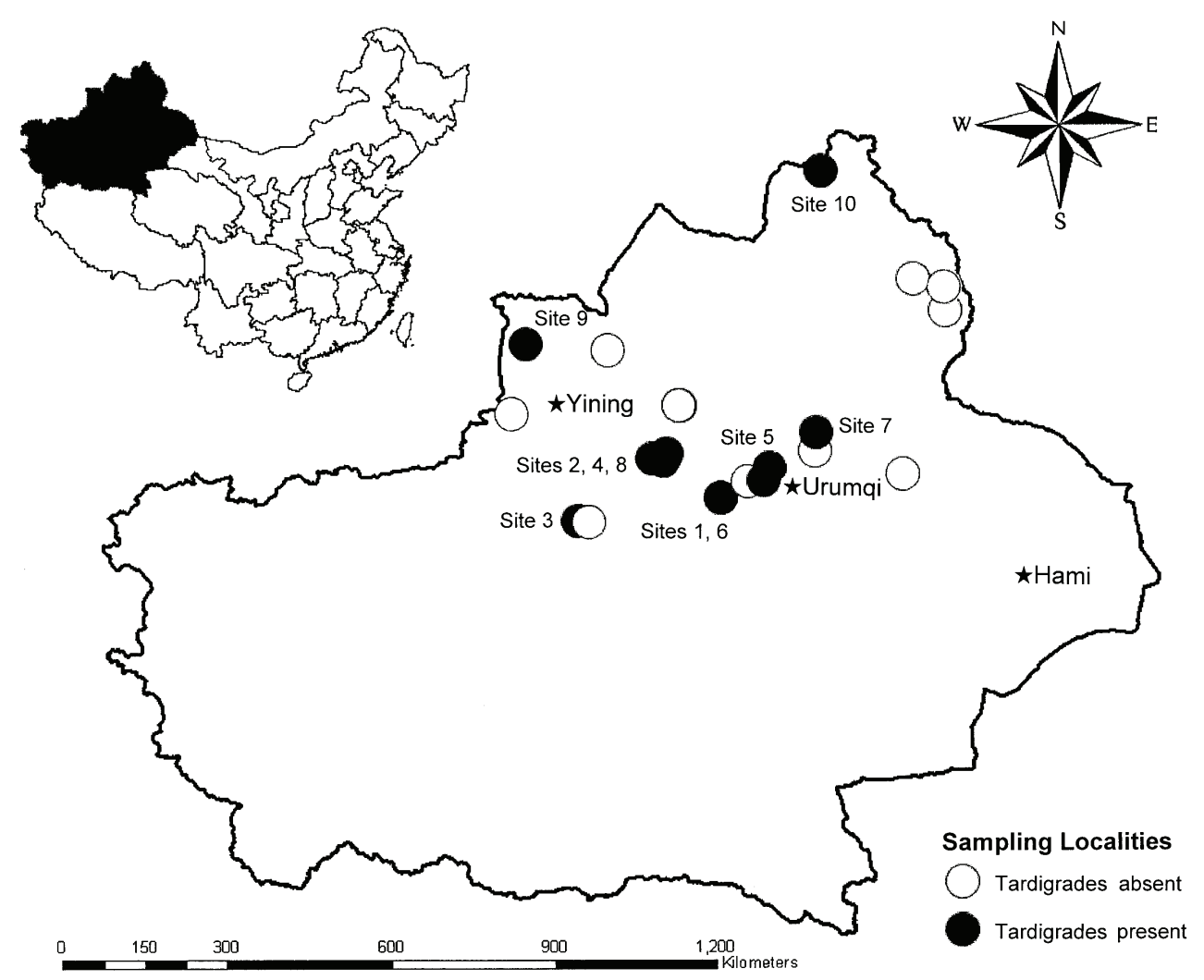

Fig. 1. Map of Xinjiang Region showing locations of sampling sites. Of the 270 moss samples examined, 78 from ten sites contained tardigrades. Insert shows the location of the region within China.

44.04.47 ${ }^{\circ} \mathrm{N} 84.47 .77^{\circ} \mathrm{E}, 28$ July 1995 , coll. Si He, Zhao Jian-cheng, Liu Zhong-ling.

Site 9. Guo-zi-gou (Fruit Valley), Bore-Yining highway, $1140 \mathrm{~m}$ a.s.1., $44.21 .00^{\circ} \mathrm{N} 80.59 .00^{\circ} \mathrm{E}, 4$ August 1993, coll. A. T. Whittemore with B. Tan, R.-L. Hu, J.-C. Zhao, R.-L. Zhu, M. Sulayman.

Site 10. Altai Region, Ha-la-si District, 6 July 1980, coll. Yang Chang-you.

Identification was facilitated by Ramazzotti \& Maucci (1983) plus original journal articles. Tumanov's paper (2006) on new species of Milnesium was used for identification purposes, and claw measurements of Milnesium are according to Tumanov. Measurements were only taken if a structure's orientation was optimal. Body length measurements do not include the hind legs. Buccal tube length, stylet support insertion, and the calculation of the pt ratio followed Pilato (1981). Buccal tube width was measured as the external diameter at the level of the stylet supports. Photomicrographs were taken using phase contrast microscopy.

\section{RESULTS}

Of the 270 moss specimens examined, 78 yielded tardigrades. Species identified are the following.

\subsection{Bryodelphax asiaticus (Kaczmarek \& Michalczyk 2004)}

One specimen was found, with a body length of 152 $\mu \mathrm{m}$. A transverse band without sculpture is present on the paired plates. Median plates 1 and 2 subdivided transversely, median plate 3 undivided. Terminal plate without incisions, but with grooves in the approximate location of such incisions. Cirrus A $42.1 \mu \mathrm{m}$ in length. Claws $6.9 \mu \mathrm{m}$ long, external claws smooth, internal claws with small spur.

This species was found at site 4 . Found in the same sample were Echiniscus testudo and E. trisetosus. B. asiaticus was found only in the moss Pseudoleskella catenulata (Brid. ex Schrad.) Kindb.

This species was described by Kaczmarek \& Michalczyk (2004) from Mongolia, and has not been reported from any other localities. This report represents a new country and region record.

\subsection{Cornechiniscus holmeni (Petersen 1951)}

Eighteen specimens in five samples. Body lengths 233-597 $\mu \mathrm{m}$ (ave. 483). Cuticular ornamentation similar to that of Echiniscus blumi, including granulation on the dorsal surfaces of all legs. With characteristically 
enlarged appendage A and W-shaped folds on scapular plate. Measurements for a $526 \mu \mathrm{m}$ specimen are followed in parentheses by the average and range: appendage A $46.5 \mu \mathrm{m}(37.6,18.8-50.5), \mathrm{C} 342.5 \mu \mathrm{m}$ (264.2, 92.1-387.5), D $280 \mu \mathrm{m}$ (251.7, 143.6-417.5), Dd 28.9 $\mu \mathrm{m}(29.9,22.3-39.2), \mathrm{Pd}$ (on posterior edge of pseudosegmental plate) $15.4 \mu \mathrm{m}(17.5,11.4-25.3)$, and $\mathrm{E}$ $33.2 \mu \mathrm{m}(31.2,10.9-45.1)$. Claws on legs IV $61.5 \mu \mathrm{m}$ (48.5, 11.4-65.8); collar on legs IV with one spine, 15.4 $\mu \mathrm{m}(14.5,7.9-18.3)$.

Dastych (1979) discussed some of the variation of this species, and the Chinese specimens exhibit the same variation in size and shape of the $\mathrm{Dd}$ and $\mathrm{Pd}$ spines. There is also great variation in the presence of cuticular appendages. Three specimens are missing Pd appendages, one missing $\mathrm{Dd}$, and one missing $\mathrm{D}$. Two specimens are missing one of the $\mathrm{D}$, one specimen missing one of the Pd. Two specimens had one appendage at $\mathrm{Cd}$, and one specimen with two $\mathrm{Cd}$ has one of them with a bifurcated tip. Only one tiny upwardpointed spine on an inner claw of legs IV such as was described by Dastych (1979) was observed, and this was only on the one claw of the specimen.

This species was found at sites 6,7, and 8. The only species found together with $C$. holmeni was Echiniscus testudo. Cornechiniscus holmeni was found in the mosses Grimmia tergestina Tomm. ex B.S.G., Mnium laevunerve Cardot, and Schistidium sp.

Based on reports so far, this species appears to be holarctic. It has not been previously reported from China, so this report represents a new country and region record.

\subsection{Echiniscus blumi (Richters 1903)}

Four specimens in four samples. Body lengths 152$450 \mu \mathrm{m}$ (ave. 288). Cuticle with polygonal pattern with a space between the granules. At some focal planes there appears to be a dot within the granules. Measurements for a $450 \mu \mathrm{m}$ specimen are followed in parentheses by the average and range: appendage A $59.4 \mu \mathrm{m}$ (50.4, 30.1-64.1), B $123.1 \mu \mathrm{m}(98.9,82.9-123.1), \mathrm{C}$ $165.8 \mu \mathrm{m}$ (136.0, 30.1-238.6), Cd 154.5 $\mu \mathrm{m}$ (101.5, 56.9-154.5), D $189.7 \mu \mathrm{m}$ (147.9, 46.5-226.1). Two specimens had spines at Dd of $4.0 \mu \mathrm{m}$, a different specimen had small spines at $\mathrm{E}$ of $3.5 \mu \mathrm{m}$. Claws on legs IV $26.7 \mu \mathrm{m}(31.9,26.7-37.1)$; inner claws of leg IV with spurs; collar on legs IV with 7-10 teeth. One twoclawed individual missing appendages B.

This species was found at sites 5, 6, 7, and 8. Found in the same samples with E. blumi were E. granulatus and Macrobiotus mauccii. Echiniscus blumi was found in the mosses Abietinella abietina (Hedw.) M. Fleisch and Schistidium sp.

This species has been reported from all continents except Antarctica. It has previously been reported from China (Rahm 1936-37a, 1936-37b, 1937), but this is a new region record.

\subsection{Echiniscus canadensis (Murray 1910)}

Eighty-two specimens in seven samples; one immature specimen with 2 claws per leg. Body lengths 142$355 \mu \mathrm{m}$ (ave. 273). Cuticular ornamentation similar to that of E. blumi; dorsum of all legs granulated. Measurements for a $320 \mu \mathrm{m}$ specimen are followed in parentheses by the average and range: appendage $\mathrm{A}$ $67.8 \mu \mathrm{m}$ (50.2, 19.8-92.9), Cd 81.6 $\mu \mathrm{m}$ (89.7, 13.4125.6), and Dd $56.5 \mu \mathrm{m}(29.0,6.4-56.5)$. Claws on legs IV $22.3 \mu \mathrm{m}(21.0,12.4-25.3)$; all claws of legs IV with spurs, those of the outer claws with smaller straight spurs, the inner curved downward; collar on legs IV with 9-12 teeth.

One specimen was missing the $\mathrm{Cd}$ appendages, another the Dd. One specimen had a single short filament present at $\mathrm{C}$, another a short spine at $\mathrm{D}$. Three specimens had very short spines $\mathrm{E}$ of 3.5-5 $\mu \mathrm{m}$.

This species was found at site 2. Found in the same samples with this species were E. testudo, Milnesium longiungue, and M. tardigradum. Echiniscus canadensis was found in the mosses Grimmia laevigata (Brid.) Brid., Grimmia ovalis (Hedw.) Lindb., and $G$. tergestina.

This species has been reported from all continents except Australia and Antarctica. It has previously been reported from China (Li \& Wang 2005a), but this represents a new region record.

\subsection{Echiniscus granulatus (Doyère 1840)}

Eight specimens in 3 samples. Body lengths 161-263 $\mu \mathrm{m}$ (ave. 200). Cuticular ornamentation of E. blumi type. Measurements for a $204 \mu \mathrm{m}$ specimen are followed in parentheses by the average and range: appendage A 57.4 $\mu \mathrm{m}(61.1,54.5-67.8)$, C $100.5 \mu \mathrm{m}$ (94.6, 67.8-137.0), Cd 40.1 $\mu \mathrm{m}$ (31.0, 18.8-43.6), D $109.3 \mu \mathrm{m}$ (114.1, 90.4-175.8), and Dd $37.6 \mu \mathrm{m}(32.0,18.8-47.7)$. Claws on legs IV $17.3 \mu \mathrm{m}(19.2,17.3-23.8)$; spur on inner claws of legs IV; collar on legs IV with 8-15 teeth irregular in width and spacing, occasionally bifurcated at tip.

Appendages $\mathrm{Cd}$ and $\mathrm{Dd}$ are similar in length on a specimen and both are wide spines. There were no appendages $\mathrm{C}$ in 4 specimens, and in one specimen it was only on one side. These specimens all lacked appendages B, which is a variable recognized by Ramazzotti \& Maucci (1983).

This species was found at sites 5, 7, and 8 . Found in samples with this species were E. blumi, E. testudo, and Macrobiotus mauccii. Echiniscus granulatus was found in the mosses Grimmia longirostris Hook., Schistidium trichidon (Brid.) Poelt, and Schistidium sp.

This species has been reported from all continents except South America, which has not been extensively studied, and Antarctica. Ramazzotti \& Maucci (1983) are doubtful of the North America record, but subsequently Maucci (1987) reported the species from Wyoming although he still questions the record of Higgins 
(1959). Higgin's drawings, especially because of his specimens' Cd, do not appear to be E. granulatus. This species has not been previously reported from China, and is a new record.

\subsection{Echiniscus testudo (Doyère 1840)}

Eleven specimens in four samples. Body lengths 157-350 $\mu \mathrm{m}$ (ave. 271). Cuticle with pores appearing white against a dark background when viewed with phase contrast. Measurements for a $323 \mu \mathrm{m}$ specimen are followed in parentheses by the average and range: appendage A 84.2 $\mu \mathrm{m}$ (77.6, 31.4-99.2), B $167.1 \mu \mathrm{m}$ (118.8, 67.8-167.1), C $129.4 \mu \mathrm{m}$ (107.2, 46.5-175.8), Dd $15.4 \mu \mathrm{m}(43.9,15.4-148.2)$, and E $218.5 \mu \mathrm{m}$ (193.9, 138.2-263.8). Claws on legs IV $28.2 \mu \mathrm{m}$ (24.6, 16.8$30.2)$; interior claws of legs IV with spur; collar on legs IV with 5-6 teeth.

Most of the specimens were the quadrifilis form having lateral appendages $\mathrm{A}, \mathrm{B}, \mathrm{C}$ and Dd. Two specimens were the trifilis form, lacking appendages B. Two specimens had a very short spine Cd 4-5.5 $\mu \mathrm{m}$.

This species was found at sites 2, 4, 5, 6, 8, and 9. Found in the same samples with this species were $E$. canadensis, E. granulatus, Cornechiniscus holmeni, Milnesium asiaticum, and M. tardigradum. Echiniscus testudo was found in the mosses Grimmia anodon Bruch \& Schimp, G. longirostris, G. tergestina, Lescuraea incurvata (Hedw.) E. Lawton, Pseudoleskella catenulata (Brid. ex Schrad.) Kindb., and Schistidium sp.

This species has been reported from all continents except Australia and Antarctica. This species has been previously reported from China (Rahm 1936-37b, 1937, Pilato 1974; Beasley et al. 2006), but this is a new region record.

\subsection{Echiniscus trisetosus (Cuénot 1932)}

Thirty-three specimens in five samples. Body lengths 157-370 $\mu \mathrm{m}$ (ave. 293). Cuticle sculpture of $E$. blumi type. Measurements for a $330 \mu \mathrm{m}$ specimen are followed in parentheses by the average and range: appendage A $61.9 \mu \mathrm{m}(55.1,20.3-72.3)$, C $136.1 \mu \mathrm{m}$ (93.7, 42.6-218.5). D $110.9 \mu \mathrm{m}$ (77.5, 35.6-111.4), Cd 111.4 $\mu \mathrm{m}$ (99.6, 24.8-136.1), and Dd $14.4 \mu \mathrm{m}$ (16.9, 8.4-32.2). Claws on legs IV 10.9-25.7 $\mu \mathrm{m}$ (ave. 20.9); internal claws with basal spurs, exterior claws of legs IV with two tiny spurs pointed perpendicular to the axis of the claw (not observed on all specimens); collar on legs IV with 7-8 teeth. Two individuals lacked filaments D.

This species was found at sites 2, 3, 4, and 8. Found in the same samples with this species were E. testudo and Bryodelphax asiaticus. Echiniscus trisetosus was found in the mosses Abietinella abietina, Grimmia ovalis, and Pseudoleskella catenulata.

This species has been reported from all continents except Australia and Antarctica. It has not been previously reported from China.

\subsection{Macrobiotus alekseevi (Tumanov 2005) (Fig. 2a, c)}

Five specimens in four samples. Cuticle smooth with the exception of granulation on the dorsum of the legs, color unknown. Selected morphometric values for a single specimen, followed by mean value and range $(\mathrm{n}=4)$ in parentheses: body length $315 \mu \mathrm{m}(335,315-363)$, buccal tube length $47.5 \mu \mathrm{m}(45.2,40.6-49.5)$, buccal tube outside diameter $9.9 \mu \mathrm{m}(9.7,8.4-11.9)$, pt value for buccal tube outside diameter 20.8 (21.3, 19.5-24.0), stylet supports insertion on the buccal tube $38.1 \mu \mathrm{m}$ (36.2, 31.7-41.6), pt for stylet supports insertion 80.2 (79.8, 77.0-84.0), first macroplacoid $6.4 \mu \mathrm{m}(6.4,5.9$ $7.4)$, pt value for first macroplacoid 13.5 (14.2, 13.515.0), second macroplacoid $5.5 \mu \mathrm{m}(5.5,4.5-6.4)$, pt value for second macroplacoid 11.6 (12.1, 10.4-13.6), third macroplacoid $7.4 \mu \mathrm{m}(6.1,4.5-7.4)$, pt value for third macroplacoid 15.6 (13.3, 10.4-15.6), microplacoid $4.5 \mu \mathrm{m}(4.5,4.0-5.0)$, pt value for microplacoid 9.5 (10.1, 8.1-12.3), primary branch of claws IV length 10.4 $\mu \mathrm{m}$ (11.0, 9.9-11.9), pt for primary branch of claws IV 21.9 (24.5, 21.9-27.6). These specimens were all smaller than Tumanov's (2005) specimens. The pt values of the buccal tube diameter are slightly higher than his and the range of pt values of the stylet support insertion is approximately the same. The range of $\mathrm{pt}$ values of the first two macroplacoids coincide, although the range of pt of the third macroplacoid is lower though overlapping. The range of the pt values for the microplacoid is higher than Tumanov's and the range of $\mathrm{pt}$ values of the primary branch of the fourth claws is slightly lower.

Although no eggs were found in these samples from Xinjiang Province, samples from Anhui Province did contain eggs (Fig. 2c) and allowed identification of these specimens to be confirmed.

This species was found at sites 1 and 7. No other species were found in the same samples. Macrobiotus alekseevi was found in the mosses Brachythecium albicans (Hedw.) Schimp and Schistidium sp.

This species was described from Thailand by Tumanov (2005). This is only the second report of this species, and is a new record for the country.

\subsection{Macrobiotus mauccii (Pilato 1974) (Fig. 2b, d, e)}

Two specimens in two samples. Cuticle smooth, color unknown. Body lengths 283 and $602 \mu \mathrm{m}$. Buccal tube lengths 44.1 and $60.4 \mu \mathrm{m}$; outside diameters of buccal tube 6.9 and $10.9 \mu \mathrm{m}$ (pts 15.7 and 18.1); large apophyses present. Stylet supports inserted on buccal tube at 34.7 and 46.5 (pts 78.7 and 77.0). Three macroplacoids; the first 6.4 and11.9 $\mu \mathrm{m}$, the second 4.0 and $8.4 \mu \mathrm{m}$, the third 5.5 and $8.9 \mu \mathrm{m}$. Microplacoid present, 1.5 and $4.5 \mu \mathrm{m}$. Primary branchs of claws of leg IV 11.4 and $29.7 \mu \mathrm{m}$.

Although no eggs were found in these samples from Xinjiang Province, samples from Jiangxi Province did contain eggs. Careful quantitative comparison with 

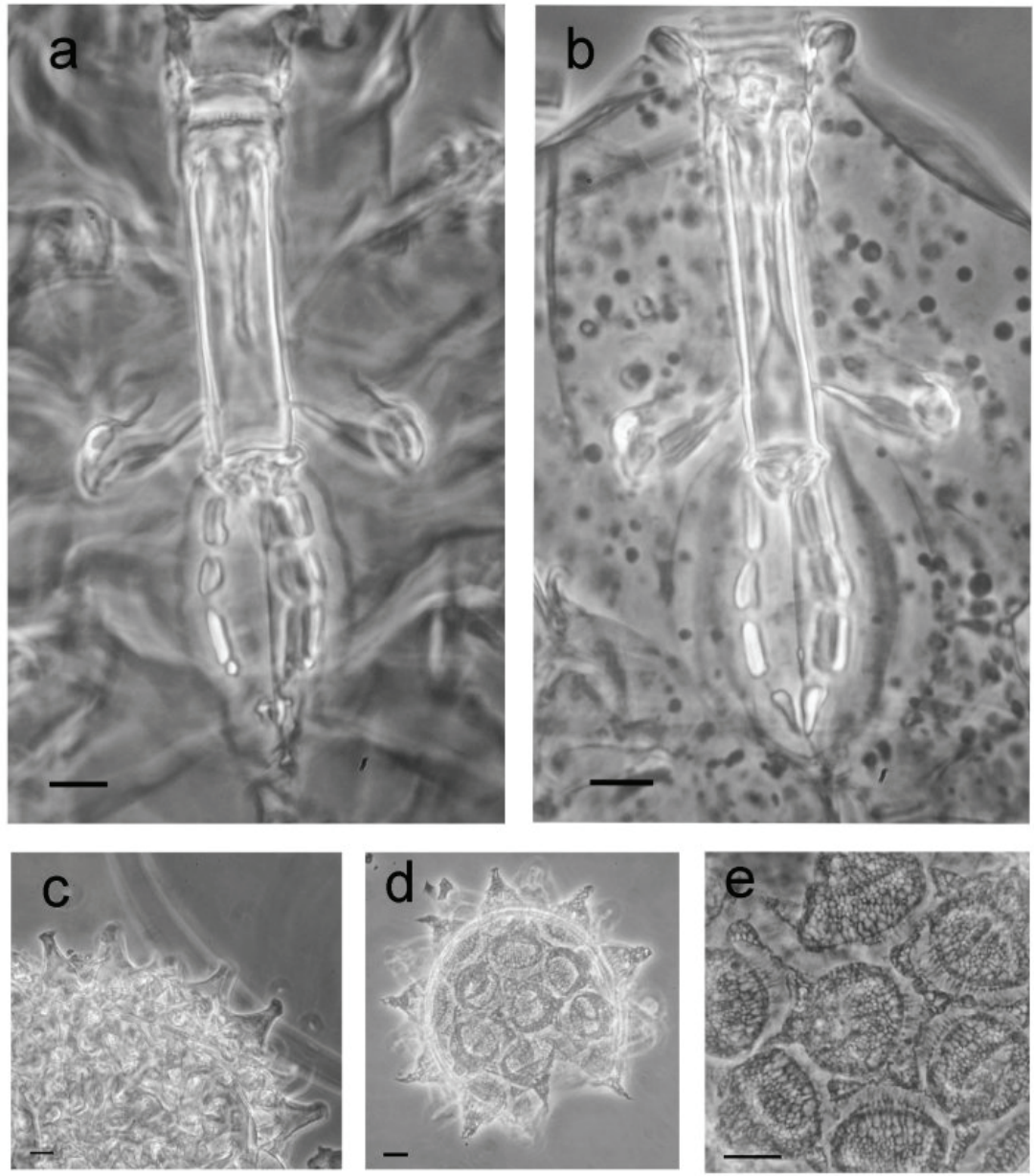

Fig. 2. a: Buccal apparatus of Macrobiotus alekseevi. b: Buccal apparatus of Macrobiotus manccii. c: Egg of M. alekseevi. d, e: Egg of M. mauccii. Scale bars $=10 \mu \mathrm{m}$.

adults from the Jiangxi sample confirmed identification of these specimens. The eggs have 8-10 projections in optical section (Fig. 2d), the tips of the projections being flexible. The projections have a ring of dots surrounding their bases, with faint lines radiating out. Between the projections there is a reticulated ridge surrounded by a relatively smooth space (Fig. 2e).

Macrobiotus alekseevi and M. mauccii are somewhat similar. In $M$. alekseevi the buccal tube tends to be shorter and wider, and macroplacoids shorter, but the ranges of these characters overlap in the two species. The microplacoid appears larger in M. mauccii in figure $2 \mathrm{a}$ and $\mathrm{b}$, but the size of this structure varies. But there are characters other than the eggs which appear to distinguish the two species. The buccal tube diameter has a pt value greater than 18.5 in M. alekseevi and less than 18.5 in M. maucci. In M. alekseevi the first macroplacoid has a bulge on the inner surface of the posterior part and the third macroplacoid has a pre-terminal constriction (Fig. 2a). It is possible that earlier reports of $M$. richtersi from China may have been either of these species.
This species was found at site 7. This species was found in the same samples with Echiniscus blumi and $E$. granulatus. Macrobiotus manccii was found in the moss Schistidium sp.

This species was described from Canton, China (Guangzhou, Guangdong Province), by Pilato (1974), later reported from South Andaman Island by Maucci \& Durante Pasa (1980) and Japan by Abe \& Takeda (2000, 2005). This is the second report of this species from China, and is a new region record.

\subsection{Milnesium asiaticum (Tumanov 2006)}

Ten specimens in four samples. Cuticle smooth with no sculpturing. Eyes present. Selected morphometric values for a single specimen, followed by mean value and range $(\mathrm{n}=4)$ in parentheses: body length $633 \mu \mathrm{m}$ (624, 587-663), buccal tube length $51 \mu \mathrm{m}$ (41.5, 37.0$51.0)$, buccal tube outside diameter $20.8 \mu \mathrm{m}$ (17.6, 15.420.8), pt value for buccal tube outside diameter 38.2 (45.7, 38.2-49.9), stylet supports insertion on the buccal tube $35.5 \mu \mathrm{m}(25.7,22.0-35.5)$, pt for stylet supports 
insertion $69.6(61.3,57.2-69.6)$, primary branch of claws IV length $30.7 \mu \mathrm{m}(28.3,25.3-30.7)$, pt for primary branch of claws IV $60.2(69.0,55.2-79.7)$, claw base plus secondary branch length $20.8 \mu \mathrm{m}$ (18.0, 15.420.8), pt for claw base plus secondary branch 40.8 $(43.5,39.5-48.1)$. Three of these four specimens were smaller than Tumanov's (2006) ten specimens, so the body part measurements are less; the range of pt values of the body parts overlaps those of Tumanov.

This species was found at sites 1,8 and 9. This species was found together with Echiniscus testudo and E. trisetosus. Milnesium asiaticum was found in the mosses G. anodon, G. tergestina, G. ovalis, and Schistidium sp.

The species description was based on specimens from Kirghizia. This is the second record of the species, and is a new record for China and the region.

\subsection{Milnesium longiungue (Tumanov 2006)}

Four specimens in two samples. Dorsal cuticle smooth. Eyespots present. Selected morphometric values for a single specimen, followed by mean value and range $(n=3)$ in parentheses: body length $607 \mu \mathrm{m}(563$, 475-607), buccal tube length $48.5 \mu \mathrm{m}(50.2,48.5-51)$, buccal tube outside diameter $14.4 \mu \mathrm{m}(16.2,14.4-17.3)$, pt value for buccal tube outside diameter 32.3 (37.2, 32.3-41.6), stylet supports insertion on the buccal tube $30.0 \mu \mathrm{m}(30.2,30.0-30.5)$, pt for stylet supports insertion $61.9(60.2,58.8-61.9)$, primary branch of claws IV length $35.2 \mu \mathrm{m}(35.0,34.7-35.2)$, pt for primary branch of claws IV $72.6(69.9,68.0-72.6)$, claw base plus secondary branch length $19.8 \mu \mathrm{m}(19.5,18.8-19.8)$, pt for claw base plus secondary branch 40.8 (38.8, 36.9-40.8). Even though these specimens were small compared to Tumanov's (2006) specimens, the measurements and pt values of most characteristics are within his ranges. The claws and their pt values are smaller than those of Tumanov, although the actual sizes of the claws are only slightly smaller that his. In both cases, only small numbers of specimens were available.

This species was found at site 1 . The only species found in the same samples with this species was Echiniscus canadensis. This species was found in the mosses Grimmia laevigata and G. ovalis.

This species was described from India, and this is the second record of this species and a new record for China and this region.

\subsection{Milnesium tardigradum (Doyère 1840)}

Five specimens in four samples. Dorsal cuticle smooth, no sculpturing. One specimen with eyes, eyes not visible in other specimens. Selected morphometric values for a single specimen, followed by mean value and range $(\mathrm{n}=3)$ in parentheses: body length $363 \mu \mathrm{m}$ (367, 350-388), buccal tube length $49.0 \mu \mathrm{m}(43.7,38.0-$ 49.0), buccal tube outside diameter $12.4 \mu \mathrm{m}(11.6,10.4-$ 12.4), pt value for buccal tube outside diameter 33.4
(31.9, 28.0-34.3), stylet supports insertion on the buccal tube $29.0 \mu \mathrm{m}(25.3,22.5-29.0)$, pt for stylet supports insertion 59.2 (58.0, 55.7-59.2), primary branch of claws IV length $21.3 \mu \mathrm{m}(19.6,16.3-21.3)$, pt for primary branch of claws IV 43.5 (44.9, 42.9-48.4), claw base plus secondary branch length $14.9 \mu \mathrm{m}(12.9,11.4-$ 14.9), pt for claw base plus secondary branch 30.4 (29.5, 28.2-30.4). The sizes of these Chinese specimens were much smaller than Tumanov's (2006) European specimens, so all of the anatomical measurements are of lesser values also. The pt values of the main branch of the claws are within Tumanov's range, the pt of the buccal tube width overlaps his range, while the pt of the stylet support insertion and that of the base plus secondary claw branch are slightly below his range.

This species was found at sites 2 and 7. Species found in the same sample with this species were Echiniscus canadensis and E. testudo. Milnesium tardigradum was found in the mosses Grimmia tergestina, G. ovalis, and Orthotrichum sp.

This species is considered to be cosmopolitan, and has been previously reported from China (Rahm 193637a, 1936-37b, 1937, Beasley \& Cleveland 1996, Beasley et al. 2006). This is a new region record.

\section{DISCUSSION}

Of the 270 moss specimens sampled, 78 yielded tardigrades. From these samples 12 species were identified. Some specimens have not been positively identified due to low numbers and/or condition of the specimen. A species of Isohypsibius close to I. qinlingensis is probably a new species, but more specimens are needed. New species of Ramazzottius, and Cornechiniscus have probably been found, but in each case only a single specimen was found. Three species of Macrobiotus were recovered, but lack of eggs prevents positive identification.

Heterotardigrada are better represented in the results than the Eutardigrada, which is related to the environment of the region and the altitude at which the samples were collected. Many of the species of Echiniscus are considered to be xerophilic (Ramazzotti \& Maucci 1983), and most of Xinjiang Region has an annual precipitation of less than $25 \mathrm{~cm}$; it has been described as having "hot dry summers, very cold dry winters, low summer rainfall, high winds" (Fullard 1968). Some of the species of Echiniscus are considered to be montane species (Maucci 1980), and the samples containing tardigrades were collected at 1,140-4,100 m a.s.1.

\section{CONCLUSIONS}

This paper reports 12 species from Xinjiang Region, seven of these being new records for China.

No conclusions can be made about associations of tardigrade species with species of mosses other than that Echiniscus testudo was found in a wider variety of moss species than any other species of tardigrade. 
Because of the relatively low number of tardigrade papers on China and the vast size of the country, it is not possible to form conclusions regarding faunal relationships of the entire country. The fauna of Xinjiang Uygur Autonomous Region does have some of the expected overlap with adjacent Kirghizia and Mongolia.

\section{ACKNOWLEDGEMENTS}

This project was funded by a National Science Foundation Biotic Surveys and Inventories grant DEB 0344313. The authors would like to thank Missouri Botanical Garden for their participation and cooperation, especially Marshall R. Crosby, and Dr. Joel Brant of McMurry University for constructing the GIS map.

\section{REFERENCES}

Abe, W., \& M. Takeda. 2000. Tardigrades from the Imperial Palace of Japan. Mem. Natl. Sci. Mus., Tokyo, 35: 165-177.

Abe, W. \& M. Takeda. 2005. Tardigrade fauna of the Tokiwamatsu Imperial Villa, Tokyo, Japan. Mem. Natl. Sci. Mus., Tokyo, 39: 503-510.

Bartos, E. 1963. Die Tardigraden der chinesischen und javanischen Mossproben. Vestn. Cesk. Spolecnosti Zool., 27: 108-114.

Beasley, C. 1999. A new species of Echiniscus (Tardigrada, Echiniscidae) from northern Yunnan Province, China. Zool. Anz., 238: 135-138.

Beasley, C. \& A. Cleveland. 1996. Tardigrada from southern Yunnan Province, People's Republic of China. Zool. J. Linn. Soc., 116: 239-243.

Beasley, C., Ł. Kaczmarek \& Ł. Michalczyk. 2006. New records of tardigrades from China, with zoogeographical remarks. Biol. Lett., 43: 13-20.

Dastych, H. 1979. Some Tardigrada from the Caucasus with a description of Isohypsibius zierhofferi sp. nov. Bull. Acad. Pol. Sci., 27: 941-947.

Fullard, H. 1968. China in Maps. George Philip \& Sons, Ltd., London: $25 \mathrm{pp}$.

Higgins, R. 1959. Life histories of Macrobiotus islandicus Richters with notes on other tardigrades from Colorado. Trans. Am. Microsc. Soc., 78: 137-154.

Kaczmarek, Ł. \& C. Beasley. 2002. Water bears (Tardigrada) of China. Zootaxa, 4: 65-76.

Kaczmarek, Ł. \& Ł. Michalczyk. 2004. A new species Bryodelphax asiaticus (Tardigrada: Heterotardigrada: Echiniscidae) from Mongolia (Central Asia). Raffles Bull. Zool., 52: 599-602.

Kaczmarek, Ł., Ł. Michalczyk \& P. Degma. 2005. A new species of Tardigrada Bryodelphax brevidentatus sp. nov. (Heterotardigrada: Echiniscidae) from China (Asia). Zootaxa, 1080: 33-38.

Li, X. \& Y. Liu. 2005. A new subspecies of the genus Diphascon and two new records of Tardigrada (Eutardigrada, Hypsibiidae, Macrobiotidae) from China. Acta Zootaxa Sinica, 30: 309-313.

Li, X., L. Su \& D. Yu. 2004. Biserovus xiae sp. n. and Doryphoribius qinlingense sp. $\mathrm{n}$., new species of eutardigrades from China. Zootaxa, 660: 1-7.

Li, X., \& L. Wang. 2005a. Two new records of Tardigrada (Echiniscidae) from China. Acta Zootaxa Sinica, 30: 591596.
Li, X. \& L. Wang. 2005b. Isohypsibius taibaiensis sp. nov. (Tardigrada, Hypsibiidae) from China. Zootaxa, 1036: 55-60.

Li, X. \& L. Wang. 2006. Two new species and a new record species of the genus Isohypsibius (Tardigrada, Hypsibiidae) from China. Acta Zootaxa Sinica, 31: 113-119.

Li, X., L. Wang \& D. Yu. 2005a. Isohypsibius qinlingensis sp. nov. (Tardigrada, Hypsibiidae) from China. Zootaxa, 980: $1-4$.

Li, X., L. Wang, Y. Liu \& L. Su. 2005b. A new species and five new records of the family Echiniscidae (Tardigrada) from China. Zootaxa, 1093: 25-33.

Mathews, G. 1937a. The Tardigrada or water bears. China J., 26: 97-105.

Mathews, G. 1937b. More tardigrades from the Far East. China J., 27: 32-35.

Maucci, W. 1980. Analisi preliminare di alcuni dati statistici sulla ecologia dei tardigradi muscicoli. Boll. Mus. Civ. St. Nat., Verona, 7: 1-47.

Maucci, W. 1987. A contribution to the knowledge of the North American Tardigrada with emphasis on the fauna of Yellowstone National Park (Wyoming). In: R. Bertolani (Ed.), Biology of Tardigrades. Selected Symposia and Monographs U.Z.I., 1. Mucchi Editore, Modena, Italy: 187-210.

Maucci, W. \& M.V. Durante Pasa. 1980. Tardigradi muscicoli delle Isole Andamane. Boll. Mus. Civ. St. Nat., Verona, 7: 281-291.

Pilato, G. 1974. Tre nuove specie di tardigradi muscicoli di Cina. Animalia, 1: 59-68.

Pilato, G. 1981. Analisi di nuovi caratteri nello studio degli eutardigradi. Animalia, 8: 51-57.

Rahm, G. 1936-37a. Vorlaeufige erste mitteilung über Tardigraden Chinas. Peking Nat. Hist. Bull., 2: 157-160.

Rahm, G. 1936-37b. Oekologische und biologische bemerkungen zur anabiotischen fauna Chinas (Nematoden und Tardigraden). Peking Nat. Hist. Bull., 2: 233-248.

Rahm, G. 1937. Tardigraden vom Yan-Chia-Ping-Tal (Nordchina). Zool. Anz., 119: 105-111.

Ramazzotti, G. \& W. Maucci. 1983. Il Phylum Tardigrada. Terza Edizione riveduta e aggiornata. Mem. Ist. ital. Idrobiol., 41: 1-1012.

Tumanov, D.V. 2005. Notes on the Tardigrada of Thailand, with a description of Macrobiotus alekseevi sp. nov. (Eutardigrada, Macrobiotidae). Zootaxa, 999: 1-16.

Tumanov, D.V. 2006. Five new species of the genus Milnesium (Tardigrada, Eutardigrada, Milnesiidae). Zootaxa, 1122: $1-23$.

Wang, L. \& X. Li. 2005. Echiniscus taibaiensis sp. nov. and a new record of Echiniscus bisetosus Heinis (Tardigrada, Echiniscidae) from China. Zootaxa, 1092: 39-45.

Yang, T. 1999. Three new species and six new records of the class Eutardigrada (Tardigrada) from China (Parachela: Macrobiotidae: Hypsibiidae). Acta Zootaxa Sinica, 24: 444-453.

Yang, T. 2002a. Three new species and one new record of the Tardigrada from China. Acta Hydrobiol. Sinica, 26: 505508.

Yang, T. 2002b. The tardigrades from some mosses of Lijiang County in Yunnan Province (Heterotardigrada: Echiniscidae: Eutardigrada: Parachela: Macrobiotidae: Hypsibiidae). Acta Zootaxa Sinica, 27: 53-64.

Yang, T. 2003. Two new species and three new records of the Tardigrada (Heterotardigrada, Echiniscidae; Eutardigrada, Milnesiidae, Macrobiotidae, Hypsibiidae). Acta Zootaxa Sinica, 28: 235-240. 